\title{
Development of Character-Integrated Hots-Based Learning Devices during the Pandemic Hot Themes and its Transfer of the Students
}

\author{
Nur Ngazizah ${ }^{1}$, Rintis Rizkia Pangestika ${ }^{2}$, Yuli Wahyuningsih ${ }^{3}$, Deny Hari Wibowo ${ }^{4}$, \\ Rahmawati $^{5}$ \\ \{nur.ngazizahumpwr@gmail.com ${ }^{1}$ \} \\ Muhammadiyah University of Purworejo ${ }^{1,2,3,4,5}$
}

\begin{abstract}
This study aims to 1) develop character-integrated HOTS-based learning tools, 2) determine the appropriateness of character-integrated HOTS-based learning tools, 3) determine students' responses to character-integrated HOTS-based learning tools, and 4) determine the feasibility of learning using based learning tools. HOTS integrated characters. The research used development research by using the 4D model (Define, Design, Develope, and Disseminate). The research subjects are V grade elementary school students for the 2020/2021 academic year. The techniques of collecting data by observation, interviews, questionnaires, and documentation. The instruments of the research are validation sheets, student response questionnaires, and learning implementation. The data analysis technique used in this research are validity and reliability tests. The results of this research on the development of learning tools are: 1) the research produced learning tools in the form of eduscience magazines, edutoys media and authentic HOTS-based character integrated assessment instruments, 2) the overall validation results of the learning tools obtained a score of 3.60 in the very feasible category, 3 ) the results the student response analysis obtained a score of $94.28 \%$ in the very good category, and 4) the mean result of learning implementation was $95.30 \%$ with the very good category. So it can be concluded that the character-integrated HOTS-based learning device is suitable for use in learning in elementary schools.
\end{abstract}

Keywords: Character, elementary school, HOTS, learning tools

\section{Introduction}

The 2013 curriculum is one of the efforts to improve the education system in Indonesia. The purpose of designing the 2013 Curriculum is so that students are able to face future challenges, globalization, advances in information technology, and a knowledge-based economy. In the $21^{\text {st }}$ century, the realm of education is expected to be able to produce human resources who have complete abilities in facing various challenges in life and have high-level thinking skills, namely critical thinking, creative thinking, problem solving and decision making. This can be achieved, of course, with the support of the learning tools used in the learning process. These learning devices are learning resources or teaching materials, teaching aids or learning media, and the assessment instruments used. However, with the current conditions, namely the covid-19 pandemic, students are required to continue to study at home and use simple learning tools. 
The regulation regarding Learning from Home or BDR was conveyed by the Minister of Education and Culture of Indonesia, namely Nadiem Anwar Makarim in Circular Number 4 of 2020 concerning Implementation of Education Policies in the Emergency of the Spread of Corona Virus Disease (COVID-19) article 2[4]. So as to achieve challenges in the century 21 with the covid-19 pandemic conditions, the learning tools used by both educators and students must be HOTS-based and to develop the character of students learning tools also with character integration. Learning carried out during covid-19 educators should not give assignments that are too burdensome to students, because this can affect the health of students. The learning that was carried out during the Covid-19 pandemic was designed to be fun, interesting so as not to bore students and remain meaningful. So that learning tools are developed in the form of eduscience magazines, edutoys media, and authentic HOTS-based assessment instruments integrated with characters.

HOTS (Higher Order Thinking Skills) according to Saputra [5] aims to improve students' thinking skills at a higher level, especially those related to the ability to think critically in receiving various types of information, think creatively in solving a problem use existing knowledge and make decisions in complex situations. According to Crowl et.al [6] the characteristics of HOTS-based learning are learning that trains students to be able to argue well, identify and develop information, discuss with each other to overcome misconceptions, and also express information that has been obtained both in everyday life. as well as in teaching and learning activities in class. Character education is a conscious and planned effort to shape a person's character or personality based on the values that exist in society [1]. The character education taught by the teacher is the basis of virtuous behavior. The characters that need to be taught are creative, patriotism, religion, tolerance, respect for achievement, discipline, hard work, honesty, independence, fond of reading, democratic, curiosity, national spirit, friendly, peace-loving, responsibility, environmental and social care. These character values become provisions in facing all the challenges that exist [2].

Asfuriyah and Nuswowati [7] suggest that science magazines are information media with the aim of delivering actual news related to science or natural science concepts. Realia media is very useful, especially for students who do not have experience with certain objects as well as a visual aid in learning that functions to provide direct experience to students [9]. Edutoys media is one of the realia learning media that can be used as a toy in an automatic way by utilizing a technology that teachers can use to convey learning material and introduce students to one of the uses of technology. According to Widoyoko [8] assessment is an activity to interpret or interpret data from a measurement based on certain criteria or standards or rules. Understanding can also be interpreted as giving meaning or determination of the quality of the results of a measurement by comparing the measurement result data with certain criteria or standards. Piaget [3] argues that the cognitive development of elementary school-age children is in a concrete operational phase, namely students will present themselves in the form of logical and rational thinking abilities towards events and events that appear concretely.

\section{Method}

The type of research used in research is research and development using the 4D model (Define, Design, Develope, and Disseminate). The research subjects were grade V elementary school students for the 2020/2021 academic year. Data collection techniques by observation, interviews, questionnaires, and documentation. The instruments used in this study were 
validation sheets, student response questionnaires, and learning implementation. The data analysis technique used in this research is validity and reliability tests.

\section{Result and Discussion}

The results obtained from this study are in the form of validation results to determine the feasibility of the developed learning tools, the results of the analysis of students' responses to the use of learning tools, and the results of the implementation of learning using the developed learning tools. The learning tools developed in this study are eduscience magazines, edutoys media, and authentic assessment instruments based on HOTS integrated characters during the Covid-19 pandemic with the hot theme and its transfer to grade $\mathrm{V}$ elementary schools. The products developed were each validated by two expert lecturers and an elementary school teacher. The result of the validation of learning device products presented in Table 1.

Table 1. Validation Results of Character Integrated HOTS-Based Learning Devices

\begin{tabular}{|c|c|c|c|c|c|c|}
\hline \multirow{2}{*}{ No. } & \multirow{2}{*}{$\begin{array}{l}\text { Products } \\
\text { Assessed }\end{array}$} & \multicolumn{2}{|l|}{ Score } & \multirow{2}{*}{$\begin{array}{l}\text { Average } \\
\text { score }\end{array}$} & \multirow{2}{*}{ Criteria } & \multirow{2}{*}{ Reliability } \\
\hline & & Lecturer & Teacher & & & \\
\hline 1. & $\begin{array}{l}\text { Eduscience } \\
\text { Magazine }\end{array}$ & 161,5 & 192 & 176,75 & Very Worth it & $91,38 \%$ \\
\hline 2. & $\begin{array}{l}\text { Edutoys Media } \\
\text { Authentic }\end{array}$ & 72 & 82 & 77 & Very Worth it & $93,50 \%$ \\
\hline 3. & $\begin{array}{l}\text { Assessment } \\
\text { Instruments }\end{array}$ & 83 & 84 & 83,5 & Very Worth it & $95,30 \%$ \\
\hline \multicolumn{2}{|c|}{ Total Score Actual } & 316,5 & 358 & 337,25 & Very Worth it & $93,39 \%$ \\
\hline
\end{tabular}

Based on the data validation results in Table 1, the learning device product in the form of eduscience magazine obtained a percentage of $91.38 \%$ with a score of 3.69 in the very feasible category. Edutoys media products get a percentage of $93.50 \%$ with a score of 3.50 which is in the feasible category and the authentic assessment instrument gets a percentage of $95.30 \%$ with a score of 3.61 which is in the very feasible category. So that the mean percentage obtained is $93.39 \%$ with a score of 3.60 with a very suitable category to be used as a learning tool in the learning process in elementary schools. Meanwhile, the results of the analysis of students' responses to learning tools were carried out by giving questionnaires to students. The results of students' responses to the learning tools developed presented in Figure 1. 


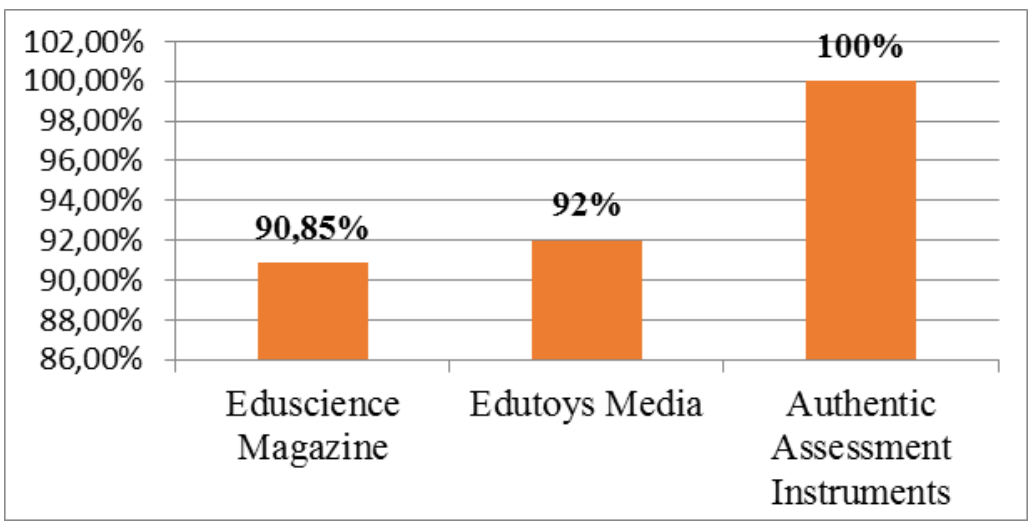

Fig. 1. Results of Students' Responses to Learning Devices Character Integrated HOTS Based

Student response data were obtained based on limited trials of fifth grade elementary school students. The limited trial with the subject of 12 students of SD Negeri 2 Tlogorejoguwo was used to determine the responses of students to the HOTS-based integrated character eduscience magazine, so that the percentage was $90.85 \%$ which was categorized as very good. The response of students to the edutoys media with a total of 10 students of SD Negeri Piji got a percentage of $92 \%$ which was in the very good category. While the response of students to the authentic assessment instrument with a total of 10 SD Negeri Wonotopo students got a $100 \%$ percentage in the very good category. So that the overall response of students to the learning tools obtained an average of $94.28 \%$ with the very good category.

The data on the results of the implementation of learning using HOTS-based learning tools integrated with characters during the Covid-19 pandemic with the hot theme and its transfer were obtained by each product for 3 meetings held at home and at school by complying with predetermined health protocols. Students are required to use a mask or faceshield, wash their hands or use a hand sanitizer, check the temperature and keep a distance. Learning is carried out for no more than one hour to prevent the spread of the corona virus. Two observers assessed the implementation of learning and then calculated it using the percentage agreement (PA) formula. The results of the implementation of learning using the HOTS-based integrated character eduscience magazine obtained a percentage of $97.41 \%$ in the very good category. The results of learning implementation using the HOTS-integrated character based edutoys media obtained a percentage of $98.49 \%$ in the very good category, and the authentic HOTS-based character integrated assessment instrument, the percentage of learning implementation is $90 \%$ with the very good category. So that the overall average percentage of the implementation of learning using HOTS-based learning tools integrated with the hot theme character and its displacement is $95.30 \%$ with the very good category. The result of the implementation of learning for HOTSbased learning tools with integrated characters during the Covid-19 pandemic with the hot theme and its displacement in grade V elementary schools presented in Figure 2. 


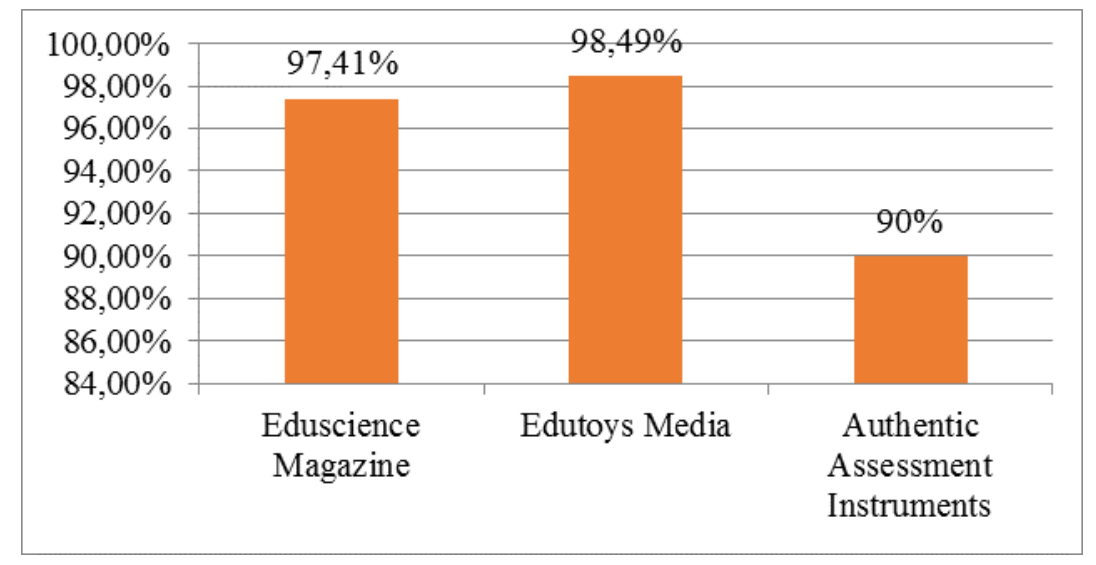

Fig. 2. Results of Learning Implementation Using Character Integrated HOTS-Based Learning Tools

\section{Conclusion}

Based on this development research, it can be concluded that this development research has produced learning tools in the form of eduscience magazines, edutoys media and authentic HOTS-based character assessment instruments integrated in the hot theme during the Covid-19 pandemic and the transfer of grade $\mathrm{V}$ elementary schools. The results of the validation of the feasibility of learning devices by two expert lecturers and elementary school teachers got an overall score of 3.60 with the very feasible category. Reliability test shows the percentage agreement of $93.39 \%$ so that the data obtained is reliable. The response of students to HOTSbased learning tools with integrated characters developed in limited trials was very good with a percentage of $94.28 \%$. The implementation of learning using HOTS-based learning tools with integrated characters through the reliability test obtained a percentage of $95.30 \%$ in the very good category.

\section{References}

[1] A. Z. Arif and S. Arin, "Debest Charter: Integration of Education Trip Center Commitments for Strengthening Character Education at SD Muhammadiyah 24 Surabaya," Journal of Elementary School Education and Learning. 1 (2b). 163, 2017. [Online]. Available: https://journal.umsurabaya.ac.id/index.php/pgsd/article/view/1154. [Accessed Oct. 8, 2019].

[2] E. D. Rinjani, "Multicultural-Based Character Education in Indonesian Language Learning as Efforts to Face the Era of the Asean Economic Community (MEA)," Proceedings of the Educatoin and Language International Conference, vol. 1, no. 1, pp. 309, 2017. [Online]. Available: http://jurnal.unissula.ac.id/index.php/ELIC/article/view/1244. [Accessed Sept. 10, 2019].

[3] G. Christoper, "The Role of Psychology in the Learning Process of Students in Schools," Journal of Warta Edition, vol. 58, 5, $2018 . \quad$ [Online]. Available: https://www.neliti.com/id/publications/290673/peranan-psikologi-dalam-proses-pembelajaransiswa-di-sekolah. [Accessed Nov. 15, 2019]. 
[4] Ministry of Education and Culture, Circular Number 4 of 2020 concerning Implementation of Education Policies in an Emergency for the Spread of Corona Virus Disease (COVID-19), Jakarta: Ministry of Education and Culture, 2020.

[5] N. H. Dinni, "HOTS (High Order Thinking Skills) and Their Relation to Mathematical Literacy Ability," Prisma Journal, pp. 171, 2018. [Online]. Available: https://journal.unnes.ac.id/sju/index.php/prisma/article/view/19597, [Accessed Nov. 13, 2019].

[6] R. A. Sani, Learning Based on HOTS (Higher Order Thinking Skills). Tangerang: Tira Smart, 2019.

[7] S. Asfuriyah and M. Nuswowati, "Development of Contextual Learning-Based Science Magazine on the Theme of Global Warming to Increase Student Interest in Learning," Unnes Science Education Journal, vol. 4, no. 1, pp. 741, 2015. [Online]. Available: https://journal.unnes.ac.id/sju/index.php/usej/article/view/4983. [Accessed Nov. 15, 2019].

[8] S. E. P. Widoyoko, Assessment of Learning Outcomes in Schools. Yogyakarta: Student Library, 2018.

[9] Y. D. Lestari, "The Use of Realia Media on the Learning Outcomes of Class IV SDN 1 SIDOKATON Students," Scientific Journal of Education, vol. 12, no. 1, pp. 102, 2019. [Online]. Available: http://jurnal.stkippgribl.ac.id/index.php/lentera/article/view/26. [Accessed Oct. 4, 2019]. 